\title{
Dematerialisation, Contracted Labour and Art Fabrication: The Deskilling of the Artist in the Age of Late Capitalism
}

\begin{abstract}
In 1966 through 1971, at least three art fabrication firms emerged in America, including Gemini G.E.L, Lippincott Inc. and Carlson and Co. The latter two firms were solely devoted to the manufacture of large-scale public sculpture, thenassociated with minimal artists, such as Donald Judd and Tony Smith. The discourse surrounding the work of these artists highlighted a shift to the conception rather than the making of a work of art and also drew attention to the industrial aesthetic fostered, perhaps, by the outsourcing of labour. Rather than adopt a contemporary reading of these practices as 'collaborative', this article aims to understand the emergence of artspecific fabrication firms within the context of late capitalism in 1960s America. Thus, the shift to 'dematerialisation' in art is read otherwise; that is, in relation to the deskilling of work - particularly in manufacturing industries - that took place across the twentieth century.
\end{abstract}

1966 through 1971 saw the emergence of at least three fabrication firms solely fabricating for artists in the United States: Gemini G.E.L., Lippincott Inc. and Carlson \& Co. In the first decade of the twenty first century the existence of artists' fabricators gained attention in art discourse, arguably for the first time since the exhibitions acknowledging fabrication in the late 1960s and 1970s. ${ }^{1}$ This visibility accompanied what Claire Bishop called the 'collaborative turn' in art, doubtlessly stemming from conversations around the English-language publication of Nicolas Bourriaud's Relational Aesthetics in 2002. Journal issues and books considering 'collaboration' often give a nod to contracted labour in art, whilst unproblematically co-opting and collapsing art fabrication into one of many collective practices. Most notable is Artforum's issue devoted to 'The Art of Production', published in 2007 amidst the contemporaneous debates on collective practice, and Julia-Bryan Wilson's 2009 Art Workers: Radical Practice in the Vietnam War era, which repeatedly emphasises Robert Morris' 'collaborative' process of working with contracted workers, including those employed by Lippincott Inc., on his 1970 Whitney show. ${ }^{2}$ Others seek to establish a legacy for the art fabricators, as in Jonathan Lippincott's 2010 book - 
Large Scale: Fabricating Sculpture in the 1960s and 1970s - devoted to images of his father's fabrication company. Rather than appropriate the aforementioned art fabricators for a larger 'collaborative' agenda, this article intends to understand the fabricators within the context in which they emerged, not only as companies making for artists but, rather, as businesses within the economic sphere. In this article, it is argued that the emergence of the art-specific fabrication businesses within this period is a response to the wider ideological conditions of a gradual deskilling of work within America throughout the twentieth century, as identified by Harry Braverman. The contracting of industrial manufacture and the deskilling of the artist from his/her manual skills is considered in terms of the wider labour conditions within the period. Beginning with the art historical context of 'deskilling' (i.e. the rejection of the artist's hand in making art), this article will look closely at the deskilling thesis as proposed by Braverman through to the Fordist ideology that dominated American life in the $1960 \mathrm{~s}$, before returning to consider the working practice of the fabricators and its relation to the 'dematerialisation of art' identified within this moment.

In 1968, Lucy Lippard and John Chandler opened their essay 'The Dematerialization of Art' with the following statement: 'As more and more work is designed in the studio but executed elsewhere by professional craftsmen, as the object becomes merely the end product, a number of artists are losing interest in the physical evolution of the work of art. The studio is again becoming a study. ${ }^{3}$ This statement testifies to an emergent phenomenon in art making in this period, that is, the separation of the idea from the physical form of the artwork. The works of art discussed in 'The Dematerialization of Art' are those of a conceptual nature. Writing in the early moments of conceptual art, and taking their lead from Joseph Schillinger's schema, Lippard and Chandler envisaged a move to a 'post-aesthetic' art to come in the near future. Although conceptual art is the article's concern, its opening statement is, furthermore, a reference to minimal works, on which Lippard had previously written. ${ }^{4}$ It was the artists associated with minimal art who began to use the early artists' 'fabricators' in America in the 1960s; Judd, LeWitt and Morris were amongst them. For 1960s conceptual art, the onus was on the idea. A conceptual artist did not necessarily produce an empirical object; if they did, it was often surplus to the idea. With minimal art, objects were produced, but not always by the artist, thus pioneering the utilisation of industrial production methods. Thus artists working 
within both movements could be said to be adopting a form of deskilling - in the sense that artists do not physically make their works - within their respective processes. The subsequent industrial aesthetic in minimal art provoked formalist commentators such as Michael Fried to detect a shift to 'objecthood' in sculpture, whilst Clement Greenberg discussed minimal works in terms of a 'non-art' aesthetic. ${ }^{5}$

The denigrating terms attributed to these works in the criticism of Fried and Greenberg signal a period of disrupture within art history. In the 1960s modernism reached its peak in America; the publication of Clement Greenberg's 'Modernist Painting' (1961) neatly reduced almost a century's worth of painting into a teleology, beginning with Manet through to the implicit contemporaneous modernist painters (presumably, colour-field painters). ${ }^{6}$ With the help of Kantian aesthetics (purporting self-criticism), modernist painting was reduced to a number of 'cardinal norms' (the boundaries of which, Greenberg argued, were tested by the modernist painters) based on its medium-specificity including flatness, two dimensionality, opticality which ultimately led to a notion of aesthetic autonomy. After adopting and continuing the (Greenbergian) formalist approach to painting, evident in his Three American Painters: Kenneth Noland, Jules Olitski, Frank Stella (1965) catalogue essay, Fried attacked the newly emergent 'literal' (now minimal) art in his essay 'Art and Objecthood' (1967). ${ }^{7}$ The work was denounced as inherently 'theatrical', due to its relationship to the viewer and the temporality of this relationship. Fried's contention thus lay with the presence of others to 'complete the work' and the reference to the outside world (objects).

Although minimal objects could be read as a sculptural response to mediumspecificity (reducing sculpture to its 'essential norms' of three-dimensionality, mass and scale, for example) they marked a departure from the 'flat', self-containted, abstract paintings heralded in art schools across the US. The three-dimensional works returned to art, reference to the outside world (something denounced in Greenberg's 'Modernist Painting') and also exposed the labour (through the choice of industrial materials and production methods) of industry which obfuscated the hand of the artist. The eradication of the hand of the artist dismantled the autonomy which Greenberg had attributed to the work of the American modernist painters from Pollock through to Jules Olitski. 
It was not only minimal artists who, in the 1960s, sought to escape the confinement of aesthetic autonomy. Conceptual artists also sought to escape the reified art object (painting) prevalent in art criticism. In his 1988 essay, 'Hans Haacke: Memory and Instrumental Reason' Benjamin Buchloh states: 'It is important to recognise that artists who continue to reject the idea of aesthetic autonomy have also had to abandon traditional procedures of artistic production (and, by implication, of course, the cognitive concepts embedded in them). ${ }^{8}$ Buchloh suggests that artists working in mid-1960s America responded to aesthetic autonomy through a form of deskilling as a mode of negation. Thus, in recognising the 'historical failure of the modernist concepts of autonomy' a dialectic emerged between deskilling as negation or resistance, and expressionism as instinctive (arguably creating an 'unalienated subject'). ${ }^{9}$ The idea of expressionism as an 'unalienated' form of (artistic) production is born from the Romantic philosophy to which much of Greenberg's criticism of this period in indebted; thus deskilling marks a break with and a negation of his approach. Buchloh cites Ian Burn: ‘...deskilling means a rupture with an historical body of knowledge - in other words, a dehistoricisation of the practice of art. ${ }^{10}$ An art history heavily reliant on the influence of critics and patrons (perhaps for the last time) had produced a definitive criteria for modernist painting, artists wishing to break with this did so in an unprecedented manner. Other art historians of this period also recognise the distance, in the new sculptural forms, from the art practices that had come before. In her canonical essay, 'Sculpture in the Expanded Field', Rosalind Krauss shows how sculpture adopted new forms that may be more aligned with architecture, landscape and site construction, for example with the earthworks. Again, these are works which require many hands and are indexically tied to the outside world, through their materials or the site-specificity. These new works, for Krauss, are a logical rupture with modernism in which the artist is now free from an ascribed medium-specificity to new possibilities within the newly 'expanded field., 11

The emergence of the art-specific fabricators occurred at the time when artists were reacting to the aesthetic autonomy of painting, taught in art schools and penetrating the museum space. Given the origins of minimalism as a reaction to Greenbergian aestheticism, it is hard to believe that the emergence of the fabrication companies was solely a response to artists' quests simply for an industrial aesthetic. Moreover, these 
were artists interested in process, as evidenced in both Morris and Haacke's work. Buchloh writes: 'Indeed an object only takes an aesthetic meaning when its referentiality has been abolished, when it no longer reminds us of the labour invested in its production. ${ }^{12}$ Both the artists associated with minimalism and those, like Haacke - working on the edges of conceptual and process-based, social art purposefully broke with the aesthetic convention, exposing the labour of others, in differing ways. For Robert Morris, it was the labour of industry, for Haacke, the participation of the public. Furthermore, the establishment of these firms extended beyond appearances to working practice. Roxanne Everett often approached artists to work at Lippincott Inc. further complicating the idea of a desired aesthetic.

In this article, it is suggested that the dematerialisation of art can be thought differently, beyond the art historical discourse and into the social and economic sphere. Through the sculptor's employment of contracted labour, dematerialisation could be understood as a reaction, conscious or not, to the implementation of a Fordist ideology in mid-twentieth century America. The artists discussed here were not sheltered from or unaware of the wider political and economic conditions under which they made work. In fact, as Bryan-Wilson's important book testifies, the artists who employed firms like Lippincott Inc. were very much invested in the political issues facing artists in the 1960s and 70s. In 1976 Carl Andre proclaimed 'the position of the artist in our society is exactly that of an assembly line worker in Detroit. ${ }^{13}$ Given the emergent climate in which artists began to consider themselves (and ask to be recognised) as 'art workers', it is not unwarranted to read the shift to contracted labour and the emergent art fabrication firms in relation to the deskilling of work that affected the wider ideology in this period.

In response to the deskilling taking place in everyday production, and the prevalent modernist ideology, it is argued here that certain artists 'deskilled' themselves (from the historical notion of skill tied to the artist's hand) through the contracting of the manufacture of their works using industrial production methods and through emphasising non-material (conceptual or political) elements in their work. However, the relationship between artist and worker in the industrial manufacturing plants was not always straightforward; the difficulties that artists experienced through working with industrial manufacturers allowed for businesses solely devoted to art fabrication 
to materialise. Gemini G.E.L, Lippincott Inc. and Carlson and Co. emerged alongside existing industrial fabricators, like Gratz Industries, who manufactured artworks for artists whilst they continued to produce everyday commodities. Beginning as a print workshop in 1966, with an artist's studio, Gemini G.E.L stands out from the group as a primarily a print-based manufacturer whose intentions were to publish prints by mature masters. It soon realised that there was a need for its services, and more, from contemporary artists and expanded its premises in 1969 to incorporate sculpture and screen-printing. Gemini claimed that Claes Oldenburg's Profile Airflow, which the company fabricated in 1968, sparked its interest in three-dimensional works. ${ }^{14}$ Subsequently, it produced Oldenberg's ambitious contribution to the 1970 World Fair in Osaka, Japan, Ice Bag - Scale A, with the assistance of Krofft Enterprises which designed the hydraulic system in Scale B. This piece was not only of a monumental scale, measuring 18 by 16 foot, but also kinetic. Gemini worked on a number of sculptural editions for artists such as Donald Judd, Ellsworth Kelly and Willem de Kooning before they closed their sculpture facilities in 1972, after Jeff Sanders left the workshop. Despite the closure of its sculpture shop, a number of employees branched off from Gemini and established their own businesses manufacturing for artists, or became freelance contractors.

In 1971, Peter Carlson branched out from Gemini G.E.L. to set up his own art fabrication unit in Los Angeles. After a brief period as an independent contractor making works in his garage, he founded Peter Carlson Enterprises (later Carlson \& Co.). ${ }^{15}$ Distinct from Gemini G.E.L., in the fact that Carlson did not wish to employ artists, Carlson focused on the manufacture of three-dimensional works rather than printmaking. Carlson himself comes from an art background; he initially studied electrical engineering before changing to study Fine Arts. The firm prided itself on its capacity to undertake any engineering possibilities and Carlson himself, speaking in 2003, denied the collaborative aspect of working with artists in favour of working for them. ${ }^{16}$ Until recently, Carlson \& Co. continued to manufacture works of art for contemporary artists like Jeff Koons alongside working on architectural projects. Sadly, the firm was hit by the recession and closed its doors in April 2010.

Founded in 1966, Lippincott Inc. of Connecticut, devoted its business to the production of large-scale sculptural works. The company was founded by Donald 
Lippincott, then a part-time industrial real-estate developer and property manager, and Roxanne Everett, a contemporary art lover who had worked in fund-raising and public relations. Industrial production was not completely alien to Lippincott; his father was the founder of an industrial design firm in New York - Lippincott and Margulies which counted the iconic Campell's soup can amongst its designs. Writing about Lippincott for the New York Times in 1976, Leslie Maitland stated: 'The sculpture factory grew out of his [Lippincott's] realisation that a need existed for a place that dealt solely with artists, to execute their large-scale ideas - freeing them from the sideline status of working at a general metalworks factory. ${ }^{17}$ This allusion to scale confirms the minimal artists' influence in the establishment of the art fabricators alongside the industrial materials (Cor-ten steel, for example). We have only to recall Michael Fried's 'Art and Objecthood' (1967) or Robert Morris' 'Notes on Sculpture' (1966) to see the importance of scale to this group of artists. The monumental scale, of which artists working with Lippincott were encouraged to undertake, was a result of the public nature of the works. Unsurprisingly, over one quarter of the artists shown in the 1974 Monumenta exhibition exhibited pieces fabricated at Lippincott Inc.

In a 1975 interview, Donald Lippincott throws light on the working practices of the firm in their early days. ${ }^{18}$ Lippincott reveals that Everett would often approach the artist to initiate the fabrication of a work, rather than have the artist approach them (Notably, Barnett Newman, an abstract expressionist - a first generation colour field painter, venturing into sculpture approached the firm to work with them). ${ }^{19}$ As such, Lippincott Inc. often selected the artists with whom it worked, fostering a certain aesthetic, whether consciously or not. Everett explains: 'Some of the artists originally chosen [to work with Lippincott Inc] were dealing with minimal forms in one way or another. ${ }^{, 20}$ Lippincott Inc. was unusual in the fact that it financially assisted the projects. Alongside this patronage of artists working at the facility, the company acquired fourteen acres of land in which it displayed the finished artworks. The onsite installation of finished artworks acted as a kind of outdoor showroom for potential buyers. Hugh Davis claims: 'The original concept of Lippincott Inc. was to provide both a fully equipped factory and financial support for the realization of large sculpture. ${ }^{21}$ Over the years, the art fabrication firm established relationships with artists with whom it would continue to work. 
These firms emerged at the height of a specific phase of capitalism in which production and consumption were both speeded up and heightened, the effects of which were becoming manifest in American society. In order to understand this period, we need to look closely at the changing economic conditions leading up to the late 1960s moment. In 1974 Braverman published Labour and Monopoly Capital: The Degradation of Work in the Twentieth Century, a seminal book that examined the changing nature and the deskilling of work in the American labour process under monopoly capitalism. The move towards deskilling was not unique to the US. Similarly, in Britain and Europe workers in manufacturing plants and elsewhere were becoming increasingly dissatisfied with the 'degradation of work' occurring in the workplace. In the wake of scientific management and Fordist production methods, workers were no longer able to apply a wide range of skills but were often subjected to repetitive tasks and stripped of their skills in the name of capital. This was not a phenomenon isolated to the sphere of work but extended far beyond the scope of Braverman's analysis and countless others' theses into the world of art.

In his analysis, Braverman returns to the late nineteenth century to locate the origins of deskilling in the workplace. He attends to scientific management and, more specifically, the methods implemented by Frederick Winslow Taylor, who cumulated a variety of scientific methods into one, the effects of which become known as Taylorism. I devote some space here to looking at scientific management and its effects from Braverman's analysis, in order to view the wider economic situation under which the production of art evolves (although this is in no way a simple mapping of scientific management onto art production).

Scientific management was a method of controlling production, introduced in the late nineteenth century, to achieve optimum production and increase the extraction of surplus. One of the distinctions between competitive capitalism and monopoly capitalism is that, in the latter, the capitalist makes money from surplus value, which becomes profit. The extraction of surplus is attributed to a form of exploitation of the worker. The surplus value is, essentially, the difference between the wages of the worker and the price of the commodity sold. Therefore, the more productive worker (i.e. the one who assembles the fastest) produced more surplus than those who worked more slowly. It is in the best interest for the capitalist to employ more efficient 
workers in order to extract more surplus value and this is where scientific management assists. Scientific management involved controlling every aspect of production and took the form of the division of labour into piecework or the implementation of an incentive system where workers are given bonuses for achieving high targets. Braverman argues that Taylorism was a response to the problem of how to best control alienated labour. ${ }^{22}$ Alienated labour, in this sense, refers to the Marxian conception, in which a worker becomes alienated from the labour power (the expenditure of their own labour) that they put into making an object. Once the object is completed, the worker is alienated from their labour at the point of exchange as their labour no longer belongs to them and confronts them as the produced commodity (this is the basis of commodity fetishism in which social relations are mediated by things). It is worthwhile noting this point as, to return to the art criticism already discussed, Greenberg's heralding of abstract expressionism, for example, is predicated on an unalienated form of artistic production. The artist is not alienated from the painting that they produce because the visible labour of the artist is inherently connected to the artist through the fetishisation of the artist's (hand) labour. The work confronts the patron as an object created by the artist rather than as a good produced by anonymous workers.

Taylorist methods attempted to gain optimum output from the workers by dividing up the work into smaller and smaller tasks. Taylorism was highly concerned with control, Braverman argues that the methods asserted '...the dictation to the worker of the precise manner in which work is to be performed. ${ }^{23}$ The worker no longer employed their own methods of labour but was asked to follow strict guides as to how a particular task was to be undertaken. Hence the scientific element: the optimum results were scientifically calculated in order to ascertain how long it would take to do certain tasks and then the 'correct' method for undertaking a job is delineated from this data. Taylor dictated that the control must move into the hands of the management, who would determine each step of the process. ${ }^{24}$

Braverman's analysis splits Taylorist methods into three principles: The first principle stated that the managers should gather all the traditional knowledge that was possessed by the workmen in the past. They then classified the knowledge reducing it to rules, laws and formulae. Braverman argues that this stage was concerned with the 
'dissociation of the labour process from the skills of the workers'. ${ }^{25}$ The second principle proposed that 'brainwork' be moved from the shop floor to the planning department. This is a key point from Braverman's thesis. He argues that, within this principle, conception was separated from execution; not mental from manual labour as it is often interpreted. (Indeed, Braverman claims that mental labour was itself subjected to the separation of conception and execution.) He argues that the dehumanisation of the labour process became crucial for the 'management of purchased labour' within the operation of the separation of conception and execution. Finally, the third principle consisted of providing the worker with fully specified instructions for each task in the form of information cards. The instructions were planned ahead by management. Braverman argues that the 'use of this monopoly over knowledge [was] to control each step of the labour process and its mode of execution. ${ }^{26}$ Braverman's thesis acknowledges an increasing deskilling of the craftworker in particular, which led to a separation of execution and conception in work. This deskilling then has a degrading effect upon the workers. Braverman proposes that the entire working class was lowered and deskilled through the implementation of scientific management.

Discussions of Taylorist control often go hand in hand with those of the Fordist assembly line, which is usually considered as a historical extension of the piecework so meticulously delineated by Taylor. In 1913 Henry Ford, owner of the Ford Motor Company, put to work an assembly line which was capable of mass producing the Model T motor car, at the Highland Park site in Detroit. The following year he implemented the five-dollar (eight hour) working day, which was crucial to his success. David Harvey writes that 1914 is the 'symbolic initiation date' of Fordism. ${ }^{27}$ It is important to stress that Ford himself did not invent the assembly line. His engineers developed an assembly line to mass manufacture the Model T, through experimenting with and adapting the existing technology (reportedly found in slaughterhouses). However, Ford was the man who changed the face of history with the particular implementation of this technology in automobile production. The assembly line affected the mode of worker-employment and the nature of labour in the plant. The new machinery became a worker substitute in many ways. As Terry Smith writes: 'The multiple-purpose machines embodied the skills that had, for centuries, been the province of the craftsmen...Rather, they concentrated on quite 
particular partial skills, certain moments in what used to be a sequence of creative labour, the frozen sections susceptible to separation, reduced to a simple motion, untiringly, infinitely repeatable. ${ }^{28}$

The machinery did not make the worker completely redundant. The upkeep and monitoring of the machines remained a human job and the labourer became another $\operatorname{cog}$ in the machinery, completing repetitive tasks on endless production lines on a much larger scale. Note that the terms 'separation' and 'repetition', associated with the Taylorist division of labour, appear in the quotation from Smith. Although there are similarities in how the labour was being divided, Smith argues that Fordist production methods were distinct from Taylorist systems because Taylor viewed the parts in terms of the whole process (including the work force); whereas Ford placed emphasis on the function of the machine with 'minimal human intervention'. ${ }^{29}$ Distinct from the approach of Taylor, Fordist production methods intensified the intervention of the machine within the labour process, leaving the worker with minimum skills.

In his Prison Notebooks, Antonio Gramsci writes that Americanism and Fordism were: '.. the biggest collective effort to date to create, with unprecedented speed, and with a consciousness of purpose unmatched in history, a new type of worker and of man. ${ }^{30}$ It is Gramsci's identification of a certain type of worker and man that contributed to the new social and economic model that became known as Fordism (Smith calls the subject of this society 'Fordised man'.) ${ }^{31}$ Ford and Fordism are separate from one another. Certainly, Ford applied new production methods and implemented the eight dollar day but it is the effect of Ford's changes on the workers which ultimately transformed the wider socio-economic and ideological conditions within society. Gramsci's writings on 'Americanism and Fordism', in his Prison Notebooks, addressed the question of whether the new production methods put to work in America constituted a new historical epoch. Harvey states that it was not until after 1945 that Fordism matured as a 'fully-fledged and distinctive regime of accumulation', which became a 'total way of life'. ${ }^{32}$ By the 1960s, Fordist ideology was embedded in the consciousness of American life. It is against this backdrop that the art fabricators discussed here emerge. 
Contemporary accounts of art fabricators often overlook the wider context in which these firms operate. Bryan-Wilson, however, before turning to focus on the political climate, notes the beginning of a decline in industrial production in 1960s' US, perhaps stressing the need to retain some of these skilled labourers for art production. $^{33}$ As earlier stated, these accounts prefer to read the fabricators in light of the new discourse on collaboration or in terms of art historical narratives, such as the quest for an industrial aesthetic, or the somewhat tiresome attribution of deskilling of art to a singular point of origin in 1917; that is, Marcel Duchamp entering his Fountain into the Society of Independent Artists exhibition. ${ }^{34}$ In her 2007 detailed trip through the history of art fabrication, 'Industrial Revolution', Michelle Kuo is quick to disavow the associations with a Taylorist production line. Despite the connotations of mass production, the industrial methods employed in the manufacturing of art are not on the same scale. Kuo writes: 'When the likes of Judd, Barnett Newman, or Sol LeWitt went to work with Treitel-Gratz, they found themselves not on some Taylorist assembly line but engaged in the dialogic dance of high-end industrial design. ${ }^{35}$ The 'dialogic dance of high-end industrial design', experienced at Treitel-Gratz, was uncommon and the marrying of art and industry was not as straightforward as the finished object would have one believe. In a 1975 interview, Robert Murray recalled how he, as an artist working in industrial plants, had to keep his hands off the machinery in some of the union shops. ${ }^{36}$ Instead he had to provide the shops with detailed diagrams for the making of his works, a model more in keeping with a Taylorist division of labour. For the most part, art and industry were too far removed to comprehend one another's language: hence the initiation of the art fabrication plants. Lippincott makes clear that this difficult relationship was one of the main reasons for establishing a company devoted to making works for artists: 'I think that recognizing the problems artist had working in other industrial situations is what led us to start with the first pieces. ${ }^{37}$

The working processes of the art fabrication firms have been largely overlooked in art discourse. The firms employed labour processes that were also subjected to a division of labour. The quest to be aligned with manual work is further visible in the language adopted by artists in this period, for example, Morris' 'repeated use of the word automation' signifying the wider deskilling in production and Andre's likening the artist to a Fordist production line worker. ${ }^{38}$ The artists may be engaging with 'high- 
end design'; however, the engineers and labourers in the art 'factory' (Lippincott) still have their work divided. In a 1975 interview, Lippincott spoke about the typical division of labour within Lippincott Inc. ${ }^{39}$ There is the initial consultation between himself, Eddie Giza (the workshop manager) and the artist, followed by the manufacturing of the artwork, which Lippincott separates into three stages. Firstly, there is the 'layout' stage, which comprises of two workers whose sole task is the laying out and cutting of the material. The welding group undertakes the second stage. Lippincott explains that there are normally four or five workers in this group, headed by Robert Giza. The third stage is the finishing, which mainly consists of sandblasting and painting. Painting was Bobby Stanford's role from which he rarely deviated. ${ }^{40}$ Lippincott claims that sometimes, rather than being divided into the three stages, one man may work on an entire piece. ${ }^{41}$ In the same way that Taylorist methods intended to combat alienated labour by dividing work (which Braverman argues dehumanises the work), having a craftworker devoted to one piece at Lippincott, may have raised questions regarding authorship. Furthermore, Lippincott did not employ artists; these were workers who were trained in specific skills within their own industries prior to coming to art fabrication. Similarly, Gemini G.E.L also divided labour into three areas and assigned a 'chief collaborator' to oversee each project. Stage one of Gemini's production consisted of the artist defining the project; stage two translated the idea into proofs and prototypes; and the final stage was the production of editions. ${ }^{42}$

Each artist worked in different ways with the fabricators they employed. Roxanne Everett stated in 1975: 'I tend to consider our "adjustment" to the artist's individual personality and specific technical requirements an overall challenge. Each artist has his own singular approach to our ambiance and to the technology itself. ${ }^{43}$ In Large Scale: Fabricating Sculpture in the 1960s and 70s, we are privy to certain artists' working process through documentary photographs and commentary. In this case, the production of Claes Oldenburg's Standing Mitt with Ball (1973) is documented. It is worth recounting the stages for the purpose of understanding the process of making a work at Lippincott. The first stage presented is Oldenburg's original model made from an altered and painted actual child's baseball mitt brought to Lippincott, who then makes a wire frame for the cloth model. Once the cloth model is complete, a half-scale (6ft) metal version is made. We are told that the half-scale work 'allowed 
Oldenburg and the Lippincott crew to explore the use of lead for the lining of the mitt. ${ }^{44}$ At full-scale, the subsequent stages become more machine-reliant. Once the quarter-inch thick weathering-steel shell is made, it is put into the brake press for shaping (notably, in the image, Oldenburg is onlooking, arms folded). Further shaping then takes place in the roller, which determines the curvature; in both of these stages, due to its scale, Mitt is suspended from a crane. The laying out of the 3/16 of an inch thick lead sheet is undertaken separately. It is roughly cut to shape and then laid on a bed of sand to support it during the forming process. In the photograph, eight men are involved in this process, including Oldenburg who appears to be watching. In the second image we see the ball being pressed into the lead to create the interior of the mitt's shape, whilst 'the crew works to support the lead form by packing sand underneath. ${ }^{45}$ The formed lead lining is then placed into the formed steel shell by crane, which acts as a cradle to return it to the shop for finishing. Once returned, we see the patron (Agnes Gund) and Oldenburg with the unfinished sculpture, ball now in place. During the finishing process, we are told that 'Mitt required many hours of Oldenburg's observation, comment, and direction...' alongside an image of Oldenburg sat in a director's chair whilst watching a worker finishing his piece. The final image is of the piece installed in Gund's garden. At each stage different workers (and different amounts of workers) are seen working on the piece. Oldenburg acts as an overseer (especially in the final stage) where, we are told, he observes for hours and comments on the finish of the piece, whilst a Lippincott employee labours.

However, other artists used Lippincott in a different way. Bryan-Wilson discusses Morris' employment of Lippincott to install his Robert Morris: Recent Works 1970 exhibition at the Whitney Museum of American Art. ${ }^{46}$ Morris chose the materials (concrete blocks, timber and steel), had them cut or made to scale (as in the case of the concrete blocks, which were actually plywood core boxes, manufactured at Lippincott, due to the weight restrictions in the gallery), and then invited the installers to leave the install up to chance. Bryan-Wilson writes: 'The pieces were made partially by chance - the workers rolled, scattered, and dropped concrete blocks and timbers, then left them to lie as they fell. ${ }^{47}$ The images of the installation included in Bryan-Wilson's book sometimes show a cigar-smoking Morris as 'worker' - for example, operating the fork-lift truck (a worker is also seen moving the dolly from underneath the forks) - but at other times, contrary to Bryan-Wilson's reading, 
although he is touching the materials (leant against a wooden timber, smoking a cigar), we could also read Morris to be overseeing the installation. Notably, the images which show the 'heavy work' omit Morris. The install took a lot of machinery and man power, due to the cumbersome nature and scale of the materials installed.

The parallel with the separation of execution and conception from Braverman's seminal analysis of the deskilling of work in the American labour process is explicit in Lippard and Chandler's aforementioned opening statement ('As more and more work is designed in the studio but executed elsewhere by professional craftsmen...') and in the above examples of both Oldenburg and Morris. The dematerialisation of art could thus be considered as an effect of the ideological changes within mid-twentieth century American society. If we interpret Lippard and Chandler's proposition in terms of Braverman's thesis, within artistic production, the artist takes control of the idea (which is a role akin to the manager rather than the factory worker). The craftsperson who executed the work is, by implication, positioned in the role of the worker. The worker, in this relationship, is not necessarily subjected to the same kind of deskilling as the worker in a manufacturing plant; production for art is distinct from mass commodity production due to the one-off nature of the pieces being made. Contrary to workers in a mainstream manufacturing plant, the workers within the fabricator models still retain their craft knowledge; it is the fabricator's knowledge and expertise that is often purchased. As we have seen, the labour is still divided into tasks; unlike mass production these are non-repetitive. The person who is being 'deskilled' in this equation is now the artist, a role traditionally associated with the acquisition of skill and craft knowledge. In essence, one could argue that the artist deskills him/herself through contracting labour. Writing in August 1975, the artist Clement Meadmore stated:

'Every work of art includes elements of art and elements of craft and in many cases the two are inseparable (the artist's touch, etc.). There are also artists including myself in whose work the execution (or craft) is completely separate from the art (or conception), and in such cases the execution is a matter of the highest possible excellence and precision. The advantages of working with craftsmen and technicians such as those at Lippincott are the possibility of a degree of precision beyond the 
capabilities of the artist, a scale beyond the limitations of the artist's studio and equipment, and the freeing of the artist to work on new projects. ${ }^{48}$

In the mid-1960s, fabricators began to manufacture work for artists, and for the most part, this practice was unquestioned. Those art historians with more formalist leanings will make the argument for the industrial aesthetic as the motivating factor in the shift to artists working alongside industry. ${ }^{49}$ However, we have to question why artists began to extensively utilise fabrication methods in 1960s/70s America. This period was a cumulating moment for the deskilling of the worker in the production plant and the new models of manufacture did not belong solely to the workplace but filtered into everyday life through Fordist ideology. Art did not remained untouched by this new way of life. The political atmosphere within the art world, typified in the establishment of the artists' unions and the visibility of the feminist and black rights movements in art, all signify and contribute towards the changing ideology of American capitalism.

As opposed to dominant labour models, whilst the labour is still being divided into tasks, in the case of the fabricators, we have seen that the craftsperson is not being stripped of his/her skills. In some ways, the labour within a fabrication firm is more interesting than in industry at large. The artist deskilled him/herself through dividing and contracting out their labour. It is the artist who employed the skills of those involved with industrial production. Braverman argues that the work of the selfemployed (i.e. handicraftsmen, artisans, tradesmen etc.) does not constitute productive labour as their labour is not exchanged for capital. He puts forward that the self-employed do not sell their labour power and do not directly contribute to the increase in capital arguing that their labour is, therefore, outside of the capitalist mode of production. ${ }^{50}$ The artist could be considered in this category. However, the artist employs productive labour in order to manufacture his/her work. Due to the nature of the labour within a work of art manufactured by a fabricator, but conceptualised by an artist, the productive and unproductive labour cannot be objectively distinguished within the object made. The labour which the artist undertakes is that of mental labour: the ideas. Rather than learning an industrial trade, the artists in question purchased the labour power (and knowledge) of others in order to manufacture their 
work. Therefore, we can ascertain that, within the manufacturing of these large-scale works of art, the conception and execution stages of both the manual and mental labour were separated.

There was a fundamental shift in the way in which American artists began to work in the 1960s, which art historians such as Buchloh and Krauss, acknowledge as a rejection of the dominant aesthetic autonomy being taught and promoted in American art schools and discourse. Within this period artists began to work differently, exposing the processes of making and employing the hands of others in doing so. Whilst more contemporary art historians like Bryan-Wilson, have understood the alignment of artist with worker as a political move against the backdrop of the Vietnam War and a demand for equal rights (for women, black and Hispanic artists, for example), including fair pay, this paper reintroduces the economic to the ideological context under which these artists worked. In looking closely at a seminal economic text contemporaneous to the period in which artists are working with fabricators, the dominant working models (in which 'deskilling' methods are employed) can be seen in tandem with the model of American ideology known as Fordism. Not only do artists begin to use the language of this economic context, but they also begin to replicate and employ the labour of industry. Through this shift in working models, firms solely devoted to art fabrication (in the tradition of foundries) are established to foster the relationship between worker and artist. However, through looking at these models we see how the (sometimes romanticized) relationship between artist and fabricator is also one in which tasks are divided and conception and execution remain separated. Looking closer at the working process further problematizes the rejection of the autonomy fostered in modernist mediumspecificity. Whilst Morris' intentions were to hand over the installation of his Whitney show to chance, the reality is one of financial exchange in which Lippincott workers are paid to, effectively, 'do their job'. If we strip back the layers, the relationship is not one of equivalents, as Bryan-Wilson envisages, but one of employer and employee. In separating conception and execution, does the artist replace aesthetic autonomy with a new form of fetishism in which the artist's ideas are now prioritised? The labeling of Oldenburg's 'director's chair' (in which he observed the finishing of his piece) with the word 'Mittseatt', although meant as a joke, is telling as to who was really in charge in the artist/worker relationship. We 
might be left to question whether the artist truly deskilled within this period or, through trying to align themselves with industrial workers, did the artist, in fact, unintentionally reskill in the white-collar working practices of management?

\footnotetext{
${ }^{1}$ Exhibitions include Artist \& Fabricator, Fine Arts Center Gallery, 1975; 14 Sculptors: The Industrial Edge, Walker Art Centre, Minneapolis, 1969 and Monumenta, Newport, Rhode Island in 1974.

2 M. Kuo, Artforum, 'Art of Production' issue, October 2007; J. Bryan-Wilson, Art Workers: Radical Practice in the Vietnam War, Berkeley, Los Angeles, London: University of California, 2009, pp.83125. Bryan-Wilson also conveys Carl Andre's working practice (in his floor pieces) as one in which the exhibition installers are seen as 'equivalents' to the artist. p.70.

${ }^{3}$ L. Lippard and J.Chandler, 'The Dematerialisation of Art' (1968) in A. Alberro and B. Stimson (eds) Conceptual Art: A Critical Reader, Cambridge, MIT, 2000, pp.46-50.

${ }^{4}$ Lippard edited and published 'Questions to Stella and Judd', Art News, 65:5, September 1966, she also wrote the essay 'Eros Presumptive' published in The Hudson Review, Spring 1967, an essay on the eroticism in minimalist language.

${ }^{5}$ M. Fried, 'Art and Objecthood', Artforum, Summer 1967. C. Greenberg, 'Recentness of Sculpture' American Sculpture of the Sixties (catalogue), Los Angeles County Museum of Art, 1967.

${ }^{6}$ C. Greenberg, 'Modernist Painting' (1961) in Charles Harrison and Paul Wood, eds, Art in Theory 1900-2000: An Anthology of Changing Ideas, Blackwell Publishing, 2003, pp.773-779.

${ }^{7}$ M. Fried, Three American Painters: Kenneth Noland, Jules Olitski, Frank Stella, New York: Fogg Art Museum, 1965 and 'Art and Objecthood' (1967) in Fried, Art and Objecthood: Essays and Reviews. Chicago: University of Chicago Press, 1998.

${ }^{8}$ B. H. D. Buchloh, 'Hans Haacke: Memory and Instrumental Reason' in Neo-Avantgarde and the Culture Industry: Essays on European and American Art from 1955 to 1975, Cambridge, Mass and London: MIT Press, 2003, p.210.

${ }^{9}$ Ibid., p. 211

${ }^{10}$ Ian Burn (1981) cited in B. H. D. Buchloh, as at note 8, p.210.

${ }^{11}$ Rosalind E. Krauss, 'Sculpture in the Expanded Field' in The Originality of the Avant-Garde and Other Modernist Myths, Cambridge: MIT Press, 1986, pp.276-290.

12 B. H. D. Buchloh, as at note 8, p.227.

${ }^{13}$ Cited in Bryan-Wilson, as at note 2, p.44.

${ }^{14}$ C .Ritchie and R. E. Fine, Gemini G.E.L.: A Catalogue Raisonné, 1966-1996, http://ww.nga.gov/gemini/essay2.htm

${ }^{15}$ See L. Moody, 'Some Assembly Required', L.A. Life supplement, Daily News, July 26th 1995.

${ }^{16}$ D. Pagel, 'The Art Factory', Calendar, August 31 2003, p.E33.

${ }^{17}$ L. Maitland, 'Factory Brings Sculptors' Massive Dreams to Fruition', The New York Times, November 24th 1976, p.35 \& p.55.

${ }^{18}$ H. M. Davis, 'Interview with Donald Lippincott', Artist \& Fabricator (exh. Cat.), Fine Arts Center Gallery, University of Massachusetts/Amherst, 1975, pp.35-44.

${ }^{19}$ Of course, there are exceptions to this, as was the case with Clement Meadmore.

${ }^{20}$ Davis, 'Interview with Roxanne Everett', Artist \& Fabricator, (exh. Cat.), as at note 6, p.45.

${ }^{21}$ Ibid., p. 10.

${ }^{22}$ Braverman, Harry (1974), Labour and Monopoly Capitalism: The Degradation of Work in the Twentieth Century, New York, London: Monthly Review Press, p.90.

${ }^{23}$ Ibid., p.90.

${ }^{24}$ Ibid., p. 100.

${ }^{25}$ Ibid., p. 112.

${ }^{26}$ Ibid, p. 118.

${ }^{27}$ D. Harvey, The Condition of Postmodernity, Cambridge, MA and Oxford, UK, Blackwell, 1990, p. 125 .

${ }^{28}$ T. Smith, Making the Modern: Industry, Art and Design in America, Chicago, University of Chicago, 1993, p.23.

${ }^{29}$ Ibid., pp.23-4.
} 
${ }^{30}$ A. Gramsci, in Q. Hoare and G. N. Smith (eds) Selections from the Prison Notebooks of Antonio Gramsci, London, Lawrence and Wishart, 1971, p.302.

${ }^{31}$ Smith, as at note 16, p. 50 .

${ }^{32}$ Harvey, as at note 15, p. $129 \&$ p. 135 .

${ }^{33}$ Bryan-Wilson, as at note 2, p.102.

${ }^{34}$ Although he briefly addresses Braverman, John Roberts overlooks the ideological effects of the deskilling thesis on art for the Duchampian argument. He dismisses the idea that art is also subject to a deskilling (via Braverman's ideas) because art production and productive labour are too distinct. J. Roberts, Intangibilities of Form: Skill and Deskilling in Art after the Readymade, London, Verso, 2007, pp.84-87.

${ }^{35}$ M. Kuo, 'Industrial Revolution', Artforum, October 2007, p.309. Treitel-Gratz is now Gratz Industries. It is notable that Kuo uses the term 'dialogic' to refer to the working practice of Lippincott, which conjures Grant Kester's 'dialogical art', a term for the new collaborative practices.

${ }^{36}$ Davis, 'Interview with Robert Murray', in Artist and Fabricator, as at note 6, p.54.

${ }^{37}$ Davis, 'Interview with Donald Lippincott', in Artist and Fabricator, as at note 6, p.35.

38 J. Bryan-Wilson, as at note 2, p.93.

${ }^{39}$ Davis, 'Interview with Donald Lippincott', in Artist and Fabricator, as at note 6, p.40.

${ }^{40}$ Ibid.

41 Ibid.

${ }^{42}$ R. E. Fine, Gemini G.E.L. Art and Collaboration, New York, Abbeville Press, 1984, pp.27-8.

${ }^{43}$ Everett in Artist \& Fabricator (exh. Cat.), as at note 6, p.47.

${ }^{44}$ J. Lippincott, Large Scale: Fabricating Sculpture in the 1960s and 1970s, New York, Princeton Architectural Press, 2010, p.135.

${ }^{45}$ Ibid., p. 138.

$46 \mathrm{~J}$. Bryan-Wilson, as at note 2, pp.82-125.

${ }^{47}$ Ibid., p.85.

${ }^{48}$ Artist and Fabricator, as at note 6, p.19.

${ }^{49}$ In utilising the term 'formalist', I refer to those critics and art historians who took their lead from Romantic philosophers such as Immanuel Kant, art historians such as Heinrich Wölfflin and the critic Clement Greenberg who prioritise the form of an artwork.

${ }^{50}$ Braverman, as at note 10, p.411. 'Even more, they [unproductive labourers] fall outside of the distinction between productive and unproductive labour, because they are outside the capitalist mode of production.' Braverman's emphasis. 